\title{
Editorial: US versus EU Leadership in Global Investment Governance
}

\author{
Bridging the Trade/Investment-Divide; In this Issue; 2015 in \\ Retrospect and Roll of Honor
}

The start of the new year is a time to look both back and into the future. 2015 was an extremely busy and no less forward-looking year for international investment law and investor-State dispute settlement (ISDS). The Transpacific Partnership (TPP), the biggest mega-regional yet, has been successfully concluded and contains a reformed version of investor-state arbitration to settle investment disputes. ${ }^{1}$ In Europe, the focus is on the Commission's proposal to create a permanent investment court, as part of the Transatlantic Trade and Investment Partnership (TTIP) and beyond. ${ }^{2}$ Arbitration, by contrast, seems almost out of the question for the way there. With these starkly contrasting visions about the future of ISDS, it is probably no exaggeration to say that we are at a historic juncture regarding the future structure of investment governance. While the United States, as indicated by TPP, favors in essence a continuation of the loosely institutionalized system of one-off arbitration, although with additional safeguards and subject to transparency, Europe aims at building new institutions. Whose approach will succeed is not only a matter of bargaining power on both sides of the Atlantic; it will be key to whose vision for governing international investment relations is more attractive at a global level.

The United States, as often in international politics, is taking a pragmatic and realistic approach. Concerns about ISDS and regulatory space are taken into account as just one element in the much broader endeavor to integrate different national economies, including between developed economies, in order to have more open markets that benefit all participating actors. No doubt,

1 The text of TPP (final, but subject to legal review for accuracy, clarity and consistency) is available at <https://ustr.gov/trade-agreements/free-trade-agreements/trans-pacific -partnership/TPP-Full-Text> accessed 16 November 2015.

2 See European Union Proposal for Investment Protection and Resolution of Investment Disputes (12 November 2015) <http://trade.ec.europa.eu/doclib/docs/2015/november/tradoc _153955.pdf> accessed 16 November 2015. 
this pragmatism is also possible because North-America already had a controversial public debate about investment disciplines when the first NAFTA cases were coming more than a decade ago. The public debate in many quarters in Europe, by contrast, is highly polarized and chiefly focused on how best to preserve regulatory autonomy at home, with more open markets seemingly perceived as a threat rather than a boon for European interests. It also comes at the inopportune moment when the Commission has already concluded its first international trade and investment agreements with Canada and Singapore. The gap between two of the world's biggest economic powers could thus not be starker. While the United States is spearheading developments in international trade and investment negotiations, Europe is still struggling to define the ultimate contours of its international trade and investment policy. At best, the European debate will result in a more principled, value-oriented and perhaps idealistic vision for global economic governance. At worst, Europe is losing global normative power because its inward-looking perspective hampers global leadership.

The Commission's proposal to create a permanent investment court is a strong vision and the text presented constitutes the first concrete step towards practical implementation. While many tricky details remain - for example how to make the court compatible with the ICSID Convention, how to enforce resulting decisions, how to integrate domestic courts better, or how to keep multilateral processes open - the Commission's political courage and craftsmanship merit applause. The proposal breathes the right spirit: to transform investor-state arbitration into a truly public, fully transparent, more predictable and balanced system of global adjudication. However, what some contributors to the debate in Europe seem to forget is that the creation of such an institution requires the agreement of partners, including, but not limited to, the United States. If it becomes a deal-breaker for TTIP, Europe is likely to lose more global influence as the United States is already turning its head towards the Pacific. This does not mean that the idea of a permanent investment court should not be pursued. On the contrary, this idea it likely better suited to deal with the problems in investment governance than the current system of oneoff arbitration. But fallback options - and this means a reformed version of investor-state arbitration, perhaps with a permanent appeals body - should not be categorically ruled out given US hesitation vis-à-vis permanent international courts. To foreclose this way forward categorically would be a great mistake, widen the transatlantic gap, and lead European visions on trade and investment governance into a cul-de-sac.

Most critically, the permanent court is currently demanded above all by pointing to shortcomings with investor-state arbitration. It is justified as a cure 
to an ill, rather than as the foundation and lodestar of a new paradigm. At the same time, side-effects and hangovers are too little considered. A permanent court could, much more than arbitration, develop its own institutional dynamics and become even more independent from government influence than is currently the case with arbitration. The courts in Luxembourg and Strasbourg are perfect examples for the unexpected dynamics permanent international courts can develop. If a permanent investment court is no more than medicine, there are less fundamental ways of curing the ills investor-state arbitration has produced. The right cures are already present in the EU's approach in its trade and investment agreements with Canada and Singapore, which are similar to provisions in TPP. They include full transparency of dispute settlement, the introduction of stricter ethics rules to ensure independence and impartiality of arbitrators, legislative counterweights in the form of committees that can issue binding interpretations, the clarification to substantive treaty standards, the introduction of (perhaps too many) exceptions, and the commitment to discuss the establishment of an appeals mechanism in the future. These elements are likely sufficient, but also necessary, to cure deficits with how investor-state arbitration has been running so far.

Yet, to make a stronger case for a permanent investment court as an independent public good, more is needed than thinking of it only as medicine for introverted sensitivities. It needs to be seen - and sold - as an entirely different ball game that can attract attention and excitement on both sides of the Atlantic (and beyond) - as a way to shape the future institutional infrastructure of the global economy in ways that are more in line with fundamental constitutional values, such as democracy, the rule of law, and the protection of economic and non-economic concerns, than the present system. It is in emphasizing these constitutional elements in an outward-looking perspective that Europe can develop a decidedly value-oriented and perhaps idealistic, but no less realistic, vision for global investment governance that could put it back into a leadership position in shaping investment law's global future.

\section{Bridging the Trade/Investment-Divide}

The start of the new year is also an occasion for reflection on the vision of JWIT to bridge the trade/investment-divide. This divide shows in different institutional structures (multilateral agreements with a centralized dispute settlement mechanism in the WTO, on the one hand, a web of many thousand bilateral agreements implemented through one-off arbitration, on the other) and the formation of different epistemic communities - international trade 
lawyers and international investment lawyers - that all too often interact too little. Yet, that the trade/investment-divide is difficult to defend has been dawning on policy-makers for quite some time now. And indeed trade and investment are increasingly seen as belonging together, economically with global value chains moving center stage in production of goods and services as well as from a regulatory perspective with the proliferation of preferential trade and investment agreements (PTIAs) and attempts to reintegrate investment issues into the WTO.

At the same time, the reintegration of trade and investment rules unchains the two formerly distinct fields and requires thinking them together (in conceptual as well as technical terms). Exclusive knowledge in either of the two fields will not suffice anymore to navigate either trade or investment rules. On the investment side, the interpretation of investment rules in a PTIA will change with the inclusion of other areas in the same agreement, as the recent decision in Al Tamimiv Oman shows. ${ }^{3}$ Similarly, new provisions in investment agreements, such as general exceptions modelled on Art. XX GATT or Art. XIV GATS, may call for expertise in WTO jurisprudence. Conversely, on the trade side, an understanding of the functioning and effect of individual international remedies is needed to design regulatory measures to pursue public policies successfully. Hence, to be an international economic lawyer will require a comprehensive perspective encompassing both trade and investment.

Most importantly, the reintegration of trade and investment should not be understood as one field colonizing the other - a danger that exists when the institutional advantage of the WTO or the superiority of the jurisprudence of the WTO Appellate is invoked vis-à-vis investment law and investor-state arbitration, or vice versa when differences between trade and investment are emphasized in order to isolate the latter from the former and undermine the claim of authority of trade lawyers. Such attitudes only alienate actors in both fields and create obstacles to the successful integration that is needed from both an economic and regulatory perspective. Instead, we should think of ways how the investment and trade communities can learn from each other, what investment law can learn from the WTO experience, both institutionally (e.g. in the current debates about creating permanent dispute settlement structures) and in resolving tensions between economic interests and competing concerns, such as human rights, the environment or development, an area where the WTO has had a much longer experience. Conversely, trade law and trade lawyers have much to learn from investment law. The proliferation of

3 See Adel A Hamadi Al Tamimi v Sultanate of Oman, ICSID ARB/11/33, Award (3 November 2015) paras 387-390. 
PTIAs, for example, and the problems this creates, is an area where creative solutions can draw on debates about fragmentation and system-building in international investment law. Similarly, investment dispute settlement may have a lesson or two to teach to trade law on questions of effective dispute settlement and procedure. What is important, in the end, is to respect each other's expertise and realize that the reintegration between trade and investment is not a one-way street.

Scholarship, in my view, has an important role to play in bridging the gap, in showing where commonalities are most obvious and interaction most fruitful, but also where tensions and conflicts exists and how they can be mitigated. For this purposes, an active thinking about problems from both a trade law and an investment law angle is important, as well as studies that explore where and how both fields can best learn from each other. JWIT expressly wants to be a platform for encouraging scholarship that bridges the trade/investment-divide, that considers a certain issue from both the angle of international trade and international investment law, that considers the interaction between trade and investment rules and institutions, that compares regulatory approaches in trade and investment law and the problem-solving strategies adopted in each field and more generally that considers what investment law can learn from trade law and vice versa. In that sense, JWIT understands itself not only as a journal focusing on issues relating to foreign investment in the narrow sense. Instead, we want to embed international investment relations into broader questions of international economic governance and thereby help to bridge the trade/investment-divide. JWIT wants to be a journal for the investment as much as for the trade community.

\section{In this Issue}

The content of the present issue is a good example of the type of scholarship that bridges the trade/investment-gap. Andrew D. Mitchell, Elizabeth Sheargold, and Tania Voon undertake a comparative analysis of how WTO and investment law enshrine and contribute to good governance in respect of procedural fairness, transparency, and reasonable administration of government measures. Despite textual differences between both regimes, they stress commonalities of the underlying approaches and philosophies and support mutual cross-fertilization in dispute settlement. Rudolf Adlung's article also engages in a comparative exercise, this time focusing on commonalities and mutual inconsistencies of how foreign investments in services are addressed in investment treaties and under GATS. He identifies scope for conflict-preventing 
initiatives but also emphasizes the need for a forum to integrate trade and investment in services more actively. Finally, Luis M. Hinojosa-Martínez tackles an issue that is key to how trade and investment law can interact in the future, namely the scope of the EU's competence for foreign investment. He argues that attention must be paid not only to the provisions on the EU's Common Commercial Policy, but also to the rules on free movement of capital, which have an express external dimension that may serve as a basis for EU competence beyond the narrow category of foreign direct investment. Four case comments and two book reviews round off this issue.

\section{5 in Retrospect and Roll of Honor}

Last, but not least, the beginning of a new year is a time to say thank you. In 2015, JWIT published a total of 1131 pages. It included 29 articles (of which 5 formed part of a Special Issue on jus post bellum and 12 of a Special Issue on investment law in Asia), seven case comments, three book review essays, eight book reviews, and three editorials by authors of great diversity in terms of perspective, professional background, geographical provenance, gender, and age. All of this would not have been possible without the unfailing help of JWIT's editorial team. Thank you!

Equally important has been the support of colleagues who agreed to peer-review submissions last year. These were Jan Asmus Bischoff, Jonathan Bonnitcha, Isabel Feichtner, Sotonye Frank, Lukasz Gruszczynski, Ousseni Illy, Makane Mö̈se Mbengue, Alex Mills, Mona Pinchis, Evgeniya Rubinina, Frédéric Gilles Sourgens, Catharine Titi, Leon Trankman, and Michael Waibel. JWIT, its authors and readers are much obliged for this generous support!

Stephan W. Schill 